\title{
KONFLIK POLITIK PADA NOVEL HANUM: ANALISIS WACANA KRITIS
}

\section{POLITICAL CONFLICT IN HANUM NOVEL: CRITICAL DISCOURSE ANALYSIS}

\author{
Feni M. Muksin \\ Fakultas Ilmu Budaya, Universitas Khairun \\ Jalan Jusuf Abdulrahman, Gambesi, Kota Ternate Selatan \\ Pos-el: fenim09@gmail.com
}

\begin{abstract}
Abstrak
Secara umum penelitian ini difokuskan pada konflik politik dalam novel Hanum karya Mustofa W. Hasyim akibat praktik kuasa. Fokus penelitian ini dijabarkan menjadi tiga, yaitu (1) praktik kuasa pada sektor hukum, (2) praktik kuasa pada sektor ekonomi, dan (3) praktik kuasa pada sektor budaya. Tujuannya untuk mengungkapkan konflik politik akibat praktik kuasa dalam novel tersebut. Jenis penelitian ini adalah kualitatif dengan pendekatan analisis wacana kritis Norman Fairclough. Konflik politik pada novel Hanum muncul akibat adanya praktik kuasa pada sektor hukum, ekonomi, dan budaya. Praktik tersebut muncul sebagai nilai ekperiensial, relasional, dan ekpresif pada teks dan partisipan. Partisipan menunjukkan keyakinan, identitas sosial, dan hubungan sosial melalui penggunaan kalimat deklaratif dan interogatif serta penggunaan metafora.
\end{abstract}

Kata kunci: konflik politik, novel Hanum, analisis wacana kritis

\begin{abstract}
Abstrack
In general, this study focused on political conflict in the Hanum novel by Mustofa W. Hasyim due to the practice of power. The focus of this research is elaborated into three, namely (1) the power practice in the legal sector, (2) the power practice in the economic sector, and (3) the power practice in the cultural sector. Its aim is to reveal political conflicts due to the practice of power in the novel. The type of research is qualitative with Norman Fairclough's critical discourse analysis approach. The political conflict in Hanum's novel arose due to the practice of power in the legal, economic and cultural sectors. Its appears as experiential, relational, and expressive values in the text and participants. The participants demonstrate beliefs, social identity, and social relations through the use of declarative and interrogative sentences and the use of metaphors.
\end{abstract}

Keywords: political conflict, Hanum novel, critical discourse analysis

\section{Pendahuluan}

Bentuk resistensi melalui karya sastra munculnya di Indonesia dilatarbelakangi adanya ketidakadilan yang didominasi oleh kapitalisme maupun neoliberalisme. Menurut Noor (2001: 88-89), sastra di Indonesia muncul akibat resistensi terhadap dominasi Barat dalam bidang politik dan kultural yang banyak muncul pada masa itu.

Salah satu karya sastra fenomenal yang muncul pada masa kolonialisme Belanda di
Indonesia adalah novel Max Havelaar karya Multatuli. Resistensi dalam novel ini juga timbul karena masalah politik ekonomi liberal tahun 1870-an yang hanya mengalihkan eksploitasi ekonomi di Indonesia dari pemerintah ke pihak kapitalis.

Sastrawan angkatan 45 muncul di tengahtengah dinamika kebangsaan dan perjuangan kemerdekaan. Pelopor angkatan ini adalah Chairil Anwar dengan karya menumentalnya "Krikil Tajam”, "Deru Campur Debu”, “Aku 
Binatang Jalang", dan lainnya. Tahun 1950-an sampai 1960-an munculnya dinamika perlawanana terhadap kolonialisme. Spirit perjuangan lahir dari para sastrawan salah satunya Taufik Ismail (MM, 2009: 2-3).

Kini karya sastra modern, seperti karya Seno Aji Gumilar, novel dengan judul "Saman" karya Ayu Utami, novel dengan judul "Nyali" karya Putu Wijaya lahir untuk menyikapi masalah sosial dan politik. Novel Ngalim Februana dengan judul "Menolak Panggilan Pulang" yang menyikapi masalah kebudayaan. Termasuk novel Hanum karya Mustofa W. Hasyim.

Hal ini memberikan gambaran bahwa karya sastra (novel) muncul sebagai resistensi terhadap praktik-praktik kuasa. Dengan demikian, sudah sejak lama karya sastra dianggap sebagai teks yang mengejawantahkan masalah-masalah kehidupan manusia sehari-hari.

Masalah kehidupan yang dihadirkan dalam teks-teks sastra penting dikaji untuk mengungkapkan makna dan nilainya. Citra kehidupan dengan segala bentuk problematikanya diungkapkan dengan bahasa sastrawan secara tersirat dan tersurat serta penuh gaya estetis.

Penggunaan bahasa secara estetis yang berorintasi imajinasi dan fiktif menjadi ciri umum wacana sastra. Namun, tidak menutup kemungkinan terdapat kandungan makna faktual bahkan sama seperti kenyataan (Bahasa, 2010: 11). Hal ini disebabkan bahasa digunakan sebagai sarana komunikasi, pengetahuan, ideologi bahkan memanipulasi dan menyesatkan (Budiwati, 2011: 229). Fungsi bahasa lainnya adalah fungsi sosial, fungsi kebudayaan, fungsi ekspresif, dan pendidikan (Nurgiyantoro, 2017: 20-21).

Novel sebagai karya sastra merupakan hasil imajinasi dan kontemplasi sastrawan atas kejadian di sekitarnya. Berdasarkan bentuknya novel digolongkan ke dalam wacana naratif. Wacana ini menceritakan suatu peristiwa.

Menurut Ian Watt dikutip Tuloli (2000: 17), novel adalah suatu ragam sastra yang memberikan gambaran pengalaman manusia, kebudayaan manusia yang disusun berdasarkan peristiwa, tingkah laku tokoh, waktu dan plot, suasana, dan talar.

Novel tetap menjadi salah satu media untuk melakukan resistensi. Melalui keindahan seni bahasa sejak zaman kolonial sampai sekarang sastra tetap hadir dan menyuarakan kegelisahan masyarakat kecil. Menyuarakan berbagai bentuk penyimpangan kekuasaan dan melakukan perlawanan terhadap kesewenangwenangan para pemegang kekuasaan.

Novel Hamun karangan Mustofa W. Hasyim dikaji dalam penulisan ini merupakan salah satu novel yang menggambarkan konflik antara masyarakat dan kekuasaan. Novel ini terkandung ide dan maksud tentang penyadaran bersama bahwa penjajahan itu masih ada bahkan makin mengada.

Novel ini terkandung semangat pembebasan dan perlawanan terhadap penjajahan itu, khususnya terhadap penjajah ekonomi yang ulahnya dianggap menyesakkan dada. Novel ini juga termuat berbagai alternatif taktik dan strategi perjuangan, pembebasan, dan perlawanan terhadap kaum penjajah ekonomi (Hasyim, 2009:xi).

Adanya praktik kuasa ideologi terhadap masalah hukum, ekonomi, dan kebudayaan pada novel Hanum perlu diungkapkan dalam perspektif kritis. Tujuannya mengungkapkan bagaimana praktik diskursif ini terjadi dan bagaimana latar konteksnya.

Penelitian terkait novel Hanun karya Mustofa W. Hasyim pernah dilakukan oleh Putri, dkk., (2013). Penelitian ini berfokus pada ideologi tokoh utama (wanita) dan tokoh pendukungnya. Perbedaan penelitian Putri dkk., dengan penelitin ini terletak pada fokus penelitiannya. Peneliti ini menganalisis konflik politik dengan pendekatan Analisis Wacana Kritis (AWK) Norman Fairclough.

Analisis model Fairclough mewakili metode dan teori yang paling cepat perkembangannnya di bidang komunikasi, budaya, dan masyarakat. Hal ini disebabkan Fairclough mengobinasikan analisis teks, praktik kewacanaan, dan praktik sosial budaya dalam sebuah wacana (Jorgensen \& Phillips, 2002: 60).

Analisis wacana kritis muncul secara khusus untuk mengaji bahasa dalam perspektif 
ideologi yang di dalamnya terkandung ketidaksetaraan, ketidakadilan, dan ketidaksamaan baik disadari maupun tidak. Tujuannya memberikan penyadaran dan pemberdayaan kepada publik bahwa terjadi praktik diskursif melalui penggunaan bahasa.

Analisis wacana kritis memandang wacana tidak bukan lagi sekedar susunan kata atau pernyataan yang terdapat dalam teks, melainkan mengandung gagasan, konsep atau efek.

Gagasan tersebut terkait konteks tertentu, sehingga dapat memengaruhi perspektif dan tindakan. Analisis wacana kritis memberikan kontribusi terhadap relasi kuasa yang tidak seimbang terhadap kelompok sosial, gender, serta minoritas dan mayoritas (Bahasa, 2010: 12). Analisis wacana kritis merupakan analisis bahasa dalam penggunaannya melalui perspektif kritis (Darma, 2014: 27).

Novel dapat dianalisis dari perspektif kritis. Analisis Wacana Kritis (AWK) mengsung tema utamanya adalah semata-mata mengungkap kekuasaan, dominasi dan kesetidaksetaraan dilakukan, direpreduksi yang dilawan melalui teks secara tertulis dalam konteks sosial dan politis.

Analisis wacana kritis memiliki cakupan kajian pada pendidikan dan sastra. Oleh sebab itu, dalam sudut pandang wacana kritis, setiap teks pasti ada ketidaknetralan dari kepentingan tertentu. Dengan kata lain, tidak ada wacana yang vakum secara sosial.

Analisis wacana kritis bertujuan mengungkapkan bagaimana konflik politik yang terdapat pada novel Hanum karya Mustofa W. Hasyim. Konflik ini akan dikaji pada subkonflik berupa hukum, ekonomi, dan kebudayaan.

Istilah konflik politik dalam ilmu politik menurut Subakti (1992: 151), dikutip (Februana, 1994: 9) adalah seringkali dikaitkan dengan kekerasan, seperti kerusuhan, kudeta, terorisme, dan revolusi. Konflik politik dirumuskan secara longgar sebagai perbedaan pendapat, persaingan, dan pertentangaan di antara sejumlah individu, kelompok, ataupun organisasi dalam upaya mendapatkan dan atau mempertahankan sumber-sumber dari keputusan yang dibuat dan dilaksanakan pemerintah.

Secara sempit konflik politik dapat dirumuskan sebagai kegiatan kolektif warga masyarakat yang diarahkan untuk menentang kebijakan umum dan pelaksanaannya, menentang perilaku penguasa beserta segenap aturan, struktur, dan prosedur yang mengatur hubungan-hubungan di antara partisipan politik.

Menurut Soekanto (1990: 399), politik adalah suatu ketidaksesuaian antara unsurunsur kebudayaan atau masyarakat yang membahayakan kehidupan kelompok sosial. Atau menghambat terpenuhinya keinginankeinginan pokok warga kelompok sosial tersebut, sehingga terjadinya kepincangan ikatan sosial. Hal ini jugalah yang akan menimbulkan konflik sosial dan politik di dalam masyarakat.

Konflik didefinisikan sebagai satu bentuk perbedaan atau pertentangan ide, faham dan kepentingan di antara dua pihak atau lebih. Pertentangan ini bisa berbentuk non-fisik, bisa pula berkembang menjadi bencana fisik. Konflik dapat berkadar tinggi dalam bentuk kekerasan dan berkadar rendah yang tidak menggunakan kekerasan.

Ahli konflik mendefinisikan sebuah hubungan-pertentangan sebagai konflik manakala hubungan-pertentangan itu bersifat langsung, yakni ditandai oleh adanya interaksi timbal-balik di antara pihak-pihak yang bertentangan. Selain itu, pertentangan itu juga dilakukan di atas dasar kesadaran pada masing-masing pihak bahwa mereka saling berbeda atau berlawanan (Fatah, 2010: 27).

Soekanto (2007: 99) menjelaskan bahwa peyebab konflik karena adanya perbedaan serta perubahan, misalnya perbedaan antar pribadi, perbedaan budaya, kepentingan, dan perubahan sosial.

Sipayung (2016: 23-24) konflik dapat terjadi karena adanya kelompok orang memiliki cara berbeda untuk mencapai tujuan. Konflik memiliki pengaruh besar terhadap kehidupan individu maupun kelompok.

Menurut Djatmiko (2008: 104), penyebab konflik, yaitu (1) perbedaan tujuan, kebutuhan, nilai, (2) ambisi dan kompetisi pribadi karena 
adanya promosi, kenaikan upah, yang mengakibatkan semangat bekerja, c) stress, karena tekanan ekonomi, keluarga, benturan, pertikaian, (3) perselisihan antar nilai individu, dan (4) streotip dan masalah rasial.

Konflik politik pada novel Hanum didefinisikan sebagai perbedaan dan pertentangan karena kepentingan antara dua kelompok, yaitu masyarakat dan pemerintah atau penguasa. Perbedaan tersebut memunculkan resistensi sebagai bentuk perlawanan. Kelompok masyarakat merasa dirugikan atas praktik-praktik kuasa oleh penguasa.

Praktik kuasa pada teks wacana sastra merupakan dimensi yang berhubungan dengan proses produksi dan konsumsi naskah. Praktik sosial budaya adalah dimensi yang berhubungan dengan konteks di luar naskah. Konteks ini mencakup banyak hal, seperti situasi. Lebih luas adalah konteks dari praktik institusi.

Istilah "kuasa" adalah konsep yang sungguh-sungguh abstrak, tetapi secara tidak terbatas kuasa itu amat sangat penting dalam mempengaruhi kehidupan manusia sehari-hari (Santoso, 2012: 58).

Kuasa menurut Fowler (1985: 61) kuasa adalah kemampuan (ability) yang dimiliki seseorang atau institusi dalam mengontrol atau mengendalikan prilaku dan kehidupan material lain. Dalam konteks ini kuasa adalah persoalan relasi timbal balik antara "penguasa" dan "terkuasa". Sementara itu, dalam pandangan Fairclough (1995: 1) kuasa secara konseptual memiliki dua makna, yaitu:

(1) ketidaksimetrisan yang ada pada antarpartisipan dalam peristiwa peristiwa kewacanaan (discourse events);

(2) ketidaksamaan kapasitas dalam mengontrol bagaimana sebuah teks diproduksi, didistribusikan, dan dikonsumsi dalam konteks sosial budaya tertentu (dikutip dalam Santoso, 2012:58).

Norman Fairclough berusaha menghubungkan antara teks pad level mikro dengan konteks sosial yang lebih besar dalam hal ini praktik sosial budaya. Pada tahap analisis ketiganya dilakukan secara bersamaan (Darma, 2014).
Fairclough (1995: 104) mengatakan bahwa AWK memfokuskan pada tiga fungsi, yaitu (1) representasi, relasi, dan identitas. Fungsi ini berkaitan dengan cara yang dilakukan untuk dapat memunculkan realitas ke dalam bentuk teks, (2) praktik wacana meliputi cara penulis menghasilkan teks, dan (3) praktik sosial-budaya. Praktik ini menghasilkan tiga teks, yaitu ekonomi, politik (terkait kuasa dan ideologi, dan budaya (berhubungan dengan nilai dan identitas) yang dapat memengaruhi wacananya.

Novel sebagai teks memberikan gambaran kejadian/peristiwa yang cocok dianalisis secara kritis, yakni melalui AWK. Pendekatan ini meliputi analisis teks, praktik wacana, dan analisis praktik sosial budaya. Dengan menggunakan paradigma kritis model analisis tersebut dianggap mampu membongkar "sesuatu di balik teks", termasuk hegemoni kuasa. Dengan demikian, menurut Philips (2007: 116) (dikutip Abadi, 2017: 171), tujuan AWK adalah untuk mengungkap dimensi linguistik kewacanaan, fenomena sosial dan budaya serta proses perubahan modernisasi terkini.

Berdasarkan paparan konsep, fenomena, dan teori di atas, analisis teks novel Hanum dengan pendekatan AWK Fairclough difokuskan pada konflik politik. Secara khusus mengungkapkan (1) praktik kuasa pada sektor hukum, (2) praktik kuasa pada sektor ekonomi, dan (3) praktik kuasa pada sektor budaya.

\section{Metode}

Jenis penelitian ini adalah kualitatif. Penelitian kualitatif dilakukan dengan pertimbangan untuk mengekspolarasi makna praktik kuasa pada novel Hanum karya Mustofa W. Hasyim dalam bentuk narasi bukan angka/statistik.

Menurut Creswell (2014:4) penelitian kualitatif bertujuan untuk mengekspolarasi serta memahami makna yang ditengarai bersumber dari masalah sosial atau kemanusiaan.

Pendekatan yang digunakan adalah Analisis Wacana Kritis (AWK) mengacu pada model Norman Fairclough, sekaligus sebagai pisau analisis. Analisis model ini dimulai dari (1) proses pendeskripsian teks, (2) interpretasi 
teks, dan (3) menjelaskan proses interaksi terkait dengan tindakan sosial (Fairclough, 1995: 33-3 \& 2003: 29).

1. Proses pendeskripsian teks adalah upaya membuat segmen-segmen teks pada setiap dialog tokoh pada novel Hanum. Langkah dilakukan untuk memudahkan proses deskripsi.

2. Interpretasi teks adalah langkah yang dilakukan setelah segmen-segmen teks dideskripsikan. Interpretasi teks akan ditemukan data sesuai focus penelitian.

3. Proses interaksi adalah upaya menghubungkan proses deskripsi dan interpretasi teks. Dengan demikian, makna terkait praktik kuasa pada novel Hanum dapat diungkapkan.

Sumber data penelitian adalah novel Hanum karya Mustofa W. Hasyim. Diterbitkan oleh Republika, tahun 2009. Jumlah halaman sebanyak 228. Novel ini merupakan novel remaja yang memuat suatu kondisi sosial budaya, ekonomi, dan hukum sebagai praktik diskursif. Teknik pengumpulan data adalah teknik studi dikumentasi.

Analisis konflik politik dalam perspektif AWK Fairclough melalui tiga dimensi, yakni teks (discourse), praktik wacana (discourse practice), dan praktik sosial-budaya (socialculture practice). Dalam model Fairclough teks dianalisis secara linguistik; dengan melihat kosa kata, semantik, dan tatakalimat.

Fairclough juga memasukan koherensi dan kohesivitas. Bagaimana antar kata dan antarkalimat tersebut digabung, sehingga membentuk pengertian. Semua elemen tersebut dilakukan untuk melihat tiga hal.

1. Ideasional yang merujuk pada representasi tertentu yang ingin ditampilkan dalam teks, yang umumnya membawa muatan ideologi tertentu.

2. Relasi, merujuk pada analisis bagaimana konstruksi hubungan, seperti apakah teks disampaikan secara informal atau formal, terbuka atau tertutup.

3. Identitas, merujuk pada konstruksi tertentu dari identitas, serta bagaimana personal dan identitas ini hendak ditampilkan dan digambarkan dalam teks (Darma, 2014).
Upaya memeroleh kejenuhan data, maka dilakukan triangulasi. Menurut Creswell and Miller (2000), standar pengecekan keabsahan data/temuan pada penelitian kualitatif, yaitu: (1) melakukan triangulasi, (2) melakukan member check, dan (3) melakukan audit trial.

Triangulasi data yang dilakukan adalah mengecek sumber data, teknik pemerolehan data, dan analisis data. Member check adalah tindakan memeriksa kembali serta mendiskusikan hasil dengan teman sejawat. Tahap ini diikuti dengan audit trial setelah data dihimpun. Dengan demikian, kesimpulan penelitian mengenai konflik politik akibat adanya praktik diskursif hukum, ekonomi, dan kebudayaan valid, kuat, benar, serta dapat dipertanggungjawabkan secara ilmiah.

\section{Pembahasan}

Novel Hanum menggambarkan bagaimana praktik kekuasaan dan kapitalis berada pada sektor kehidupan masyarakat dan bangsa. Sektor kehidupan seperti hukum, ekonomi, dan politik dianggap tidak berpihak kepada rakyat.

Bagaimana gambaran terjadinya konflik oleh pengarang akan dibahas satu demi satu mulai (1) praktik kuasa pada sektor hukum, (2) sector ekonomi, dan (3) sektor budaya.

Struktur masyarakat yang dikisahkan dalam novel Hanum adalah struktur masyarakat yang sudah mapan atau sudah stabil. Kondisi sosial masyarakat dalam novel Hanum peneliti melihatnya dari aspek (1) hukum, (2) ekonomi, dan (3) kebudayaan. Dengan alasan ketiga domain konflik ini yang membuat praktik kuasa dalam teks novel benar-benar bermakna.

\subsection{Praktik Kuasa dalam Sektor Hukum dan Hak Azasi Manusia}

Model praktik kuasa dalam novel Hanum dapat dikategorikan sebagai model praktik kuasa negatif. Praktik kuasa tersebut mengancam eksistensi system sosial dan politik serta struktur masyarakat. Apalagi pihak-pihak yang berkonflik menggunakan cara kekerasan untuk memperjuangkan kepentingannya dan mempertahankan sistem lama. Model praktik kuasa negatif juga 
mempunyai karakteristik dipergunakan caracara kekerasan oleh pihak yang bertikai.

Masyarakat yang digambarkan dalam novel Hanum adalah mereka yang sudah memiliki kesadaran hukum. Namun, kenyataannya justru Peraturan Daerah (Perda) dan Undang-Undang yang dirumuskan oleh pemerintah adalah pemicu konflik antara masyarakat dengan pemerintah.

Masyarakat melalui tokoh Hanum, Sukma, Maya, dan Talib dengan tegas menolak segala bentuk kebijakan pemerintah atas diberlakukannya Perda dan UndangUndang sebagaimana dijelaskan.

Menurut Kusumaatmadja (2011:75), bahwa negara hukum adalah negara yang berdasarkan hukum, di mana kekuasaan tunduk pada hukum dan semua orang sama di hadapan hukum. Salah satu tujuan dibentuknya negara adalah untuk melindungi serta mempertahankan sumber-sumber yang penting bagi negara untuk kemakmuran rakyat.

Upaya-upaya tersebut di atas selanjutnya dirumuskan dalam UUD 1945 di mana dalam perumusannya murni ide dan gagasan pemerintah sendiri dengan memperhatikan kondisi sosial budaya bangsa. Artinya, dalam setiap perumusan perundang-undangan pemerintah tidak membuka ruang bagi pihakpihak lain untuk intervensi segala bentuk perumusan undang-undang tersebut, apalagi pihak-pihak asing/negara lain.

Hukum memang bertindak keras terhadap masyarakat, tetapi hukum yang bagaimana yang dijalankan dengan ketegasan dan kekerasan itu. Dalam realitas kehidupan sehari-hari banyak dijumpai benturan antara realitas dan dinamika masyarakat dengan hukum yang berlaku. Mempertahankan hukum berarti mengambil resiko menghentikan dinamika masyarakat, sementara mengikuti realitas dan dinamika, berarti melawan status quo yang ingin dipertahankan oleh kepastian hukum (Rahardjo, 2008:3-4).

Hukum akan selalu mengikat seluruh warga negara, siapa yang melakukan tindakantindakan melawan hukum, maka patut mendapat hukuman sesuai perbuatannya tanpa memandang bulu. Namun, banyak permasalahan yang muncul akibat daripada hukum dengan berbagai alasan, misalnya materi hukum dianggap tidak mengakomodir kepentingan umum (deskriminasi) dan atau dalam prakteknya tidak sesuai dengan hukum yang telah ditetapkan.

Hal ini yang digambarkan pengarang dalam novel Hanum karya Mustofa W. Hasyim. Ini sesuai dengan yang disampaikan oleh Rohman (2009:24-26), bahwa (1) politik merupakan kegiatan yang berkaitan dengan perumusan dan pelaksanaan kebijakan umum, (2) politik adalah konflik dalam rangka mencari dan mempertahankan sumber-sumber yang dianggap penting.

Praktik kuasa dalam bentuk produk hukum dalam novel Hanum dapat dilihat pada perumusan Undang-Undang dan Perda yang tidak ada semangat membela kepentingan masyarakat dan hanya mementingkan kepentingan-kepentingan pihak tertentu, terutama pemerintah, pemodal atau pengembang dalam negeri maupun dari luar negeri. Hal ini secara eksplisit dapat dilihat pada teks berikut.

Teks [1] “....hukum-hukum, peraturan, UndangUndang, keputusan-keputusan para penguasa yang dibuat untuk mengesahkan proses pelepasan tanah dari tengah masyarakat...."(Hanum, hlm. 139140)

Teks [2] "Undang-Undang. Coba perhatikan, Undang-Undang ini dibuat oleh siapa untuk kepentingan siapa? Memang dulu wakil rakyat diberitahu apa isi Undang-Undang waktu masih berupa RUU. Wahai wakil rakyat yang terhormat, mohon dicermati isi Undang-Undang ini. Apakah ada semangat untuk memihak rakyat? Tidak. UU ini hanya berisi semangat untuk membela kepentingan pemerintah dan pemodal. Apalagi Perda-Perda yang ada." (Hanum, hlm. 178)

Teks 1 dan 2 di atas menggambarkan sudut pandang pemerintah yang dalam perumusan Undang-Undang hanya berpihak kepada penguasa, tanpa melihat kepentingan rakyat. Proses rewording (proses pengungkapan sesuatu dengan kata secara gamblang). Hal tersebut sangat mengandung nilai ideologis. Sebetulnya dari aspek kosa kata kata-kata, seperti hukum, peraturan, dan Undang-Undang merupakan manifestasi dari ideologi. Ada nilai ekspresif berupa keinginan dan pemaksaan pada teks tersebut. 
Teks 1 dan 2 menggunakan modus pernyataan dan interogatif (pertanyaan) pada teks sebagai bentuk penegasan digunakan secara dominan untuk menyampaikan ketidakberpihakan pemerintah atas produk Undang-Undang yang dirumuskan oleh pemerintah (DPR). Hal ini sekaligus memberikan gambaran bahwa adanya relasi kekuasaan antara pembuat Undang-Undang (pemerintah) dengan pihak yang memiliki modal.

Terkait dengan aspek gramatika muncul kata wakil rakyat terhormat sebagai pengganti kata Anda yang mengandung nilai ekspresional. Secara umum teks 1 dan 2 megandung nilai relasional yang negatif. Hubungan antara partisipan tidak terjalin secara baik. Selain itu, struktur teks dimanfaatkan sebagai media resistensi.

Semangat perumusan Perda dan UndangUndang di atas membuat Hanum secara tegas menolak. Hal ini disampaikan secara eksplisit sebagaimana teks 3 di bawah.

Teks [3] ... tidak! Kami semua menolak penerapan segala macam Undang-Undang, Perda, dan apa pun namanya yang bertentangan dengan hati nurani dan hak asasi masyarakat untuk memiliki tanah sendiri dan hak ekonomi untuk berusaha sendiri. Kami semua telah mendengar penjelasan dan ceramah dari bapak-bapak soal koridor hukum yang harus kami tepati. Tapi kalau hukum yang dibuat oleh bapak-bapak semua ternyata bertentangan dengan asas keadilan, apakah kami harus taati? Lebih tinggi mana kedudukannya, hukum atau keadilan? (Hanum, hlm. 179)

Hukum seakan tak berdaya di hadapan orang-orang yang memiliki kekuasaan dan relasi ke pemerintahan yang kuat, sehingga hukum selalu mengarah dan mapan hanya pada orang-orang yang lemah, sekalipun meraka belum tentu bersalah. Sebab itu, nilai ekpresif dan relasional sangat dominan pada teks 3. Partisipan saling menunjukkan identitas masing-masing. Hal ini tampak pada penggunaan kalimat deklaratif dan interogatif.

Pada teks 4 terdapat nilai ekpresi, seperti merasa heran, merasa aneh, dan meresa kecewa dan pasrah. Jadi, struktur teks dimanfaatkan untuk mengungkapkan sikap ekpresional sebagai representasi pengetahuan dan keyakinan yang terdapat pada dunia nyata.

Teks [4] "Di negeri ini, "katanya," orang yang tak bersalah bisa saja dihukum karena dianggap bersalah dan direkayasa seolah-olah memang bersalah. Sebaliknya orang-orang yang bersalah malah bisa bebas untuk membuat kesalahan yang lebih besar lagi." (Hanum, hIm. 181)

Konfigurasi kekuatan dan kepentingan dalam badan pembuat Undang-Undang, intervensi dari luar juga tidak dapat diabaikan dalam pembentukan Undang-Undang. Aktoraktor yang berkepentingan terhadap UndangUndang tidak hanya aktor negara, tetapi juga non-negara, yang semuanya memiliki relasi antara lain pemilik modal, guna menjalankan kekuasaannya. Relasi antara kekuatan asing, negara, dan pemerintah.

Teks [5] "Masyarakat sekarang harus berkelahi melawan pihak luar atau kekuatan asing yang justru lihai dan mahir berkomplotan dengan kekuatan Negara. Negara sendiri, pemerintah sendiri, Undang-Undang sendiri, dan aparat sendiri." (Hanum, hlm. 133)

Dalam perspektif inilah, maka Marx mangatakan hukum sebagai konstruksi kepentingan kapital. Berdasarkan hak milik si pemilik tanah orang miskin tidak diperbolehkan minikmati hasil tanah tersebut.

Akhirnya, masyarakat khawatir dan takut menghadapi kenyataan memertahankan tanahnya yang sudah sejak lama dibangun dengan pasar tradisional. Hal ini disebabkan mereka hidup di bawah tekanan kekuasaan pemerintah atau negara dengan sistem penerapan perundang-undangan yang kaku.

Teks [6] “...aku tidak mau dikatakan melawan pemerintah atau dihukum karena melawan negara, mendirikan pasar swasta, melanggar UndangUndang." (Hanum, hlm. 91).

Namun demikian, Hanum tetap ingin melawan dan menggagalkan rencana pemerintah. Sebab ia yakin bahwa pasar yang didirikan itu adalah murni milik masyarakat Wonomakmur.

Teks [7] "Bagus Mbah. Tolong Mbah ulurulurkan waktu sementara saya menyelidiki kasus ini. Kalau ada pihak yang mendesakkan kemauannya seperti itu pasti ada sebabnya. Saya ingin menyelidiki apa yang menjadi latar belakang kenapa ada utusan pemerintah datang ke tempat 
ini dan ingin cepat-cepat mencaplok pasar ini." (Hanum, hlm. 91)

Teks [1-7] di atas sangat jelas terjadinya dua kepentingan yang berbeda, yakni antara masyarakat, pemerintah, dan pihak pemodal. Perbedaan kepentingan dan tujuan antara kelompok ini merupakan gambaran konflik politik dalam novel Hanum.

Kalimat-kalimat didominasi kalimat atributif interogatif serta pernyataan sikap menunjukkan adanya kelompok sosial dalam proses merumuskan regulasi.

Melalui penggunaan kalimat interogatif dan berita dapat dikatakan bahwa praktik kuasa dalam diskursif relavan dengan kontrol mahasiswa kepada partisipan, yakni penguasa terhadap partisipan yang tidak memiliki kekuasaan. Menurut Fairclough (2003:53) adanya tiga pembatasan, yaitu (1) isi, (2) relasi, dan (3) subyek. Ketiga ini muncul sebagai fakta teks, tetapi saling tidak menerima.

Apa yang diucapkan atau dilakukan berkaitan dengan isi. Relasi, yaitu hubunganhubungan sosial yang dilakukan orang dalam diskursif. Hubungan sosial antar mahasiswa dengan penguasa yang dinilai tidak sinergi. Subyek, yaitu posisi partisipan penguasa dan partsipan tidak berkuasa. Dalam praktiknya hubungan sosial hanya menguntungkan pihakpihak tertentu saja.

\subsection{Praktik Kuasa dalam Sektor Ekonomi}

Kondisi ekonomi masyarakat dalam novel Hanum sebenarnya sudah pada kategori mapan. Hal ini disebabkan kesadaran masyarakat untuk menciptakan sumbersumber ekonomi secara mandiri telah ada. Dibuktikan dengan dibangunnya pasar tradisional secara swadaya di atas tanah miliknya sendiri. Namun, di tengah-tengah kemajuan itu, masyarakat harus berhadapan dengan pemerintah yang mengklaim pembangunan pasar tradisional itu melanggar aturan dan harus digusur.

Akibat kebijakan pemerintah untuk mencaplok pasar ini banyak menimbulkan kegelisahan bagi masyarakat, sebab mereka harus kehilangan pekerjaan lalu siap menganggur.

Gramatika, Volume VI, Nomor 2, Juli-Desember 2018
Hanum, Sukma, Maya, dan Talib menilai kebijakan pemerintah sebagai bentuk penjajahan ekonomi di tengah-tengah masyarakat. Pemerintah memaksa menggusur pasar tradisional ini untuk mendirikan tempattempat perbelajaan modern yang semuanya dimodali oleh investror-investor asing. Hanum dan teman-temannya sadar bahwa saat ini negara seakan dipaksa dengan politik dagang dan ekonomi global dan hanya berposisi sebagai konsumen.

Tanah-tanah di banyak pulau kemudian disulap menjadi fondasi bagi pembentukkan ruang ekonomi dan nyaris semua berada di bawah kendali modal asing. Toko-toko, mall, pasar, supermarket, dan hipermarket sebagai ruang ekonomi pun didominasi produk asing. Bahkan rumah-rumah dan tubuh kita pun ditempeli oleh produk asing. Lantas apa yang tersisa bagi bangsa ini? Nyaris tidak ada. Lewat banyak Undang-Undang, di antaranya Undang-Undang Sumber Daya Alam, maka hak rakyat atas tanahnya sendiri dilucuti.

Peraturan dan Undang-Undang yang jauh dari kepentingan masyarakat merupakan jalan masuk menuju kuasa ekonomi. Cengkraman perekonomian ini semakin kuat dan dengan cara damai dan konsesi ekonomi menjadikan bangsa terjajah yang berkepanjangan.

Teks [8] “... hukum-hukum, peraturan, UndangUndang, keputusan-keputusan para penguasa yang dibuat untuk mengesahkan proses pelepasan tanah dari tengah masyarakat pada hakikatnya adalah instrumen penjajahan ekonomi tersebut." (Hanum, hlm. 139-140)

Kondisi mental pejabat pemerintah terkesan selalu memuja para kaum pemodal (capital) dan memberikan peluang usaha kepada pihak-pihak investor untuk mengelola potensi yang dimiliki masyarakat.

Teks [9-10] "Para pejabat juga telah menjadi pemuja modal atau kapital. Mereka mengatakan, ukuran maju tidaknya sebuah daerah dapat dilihat ada tidaknya investor atau pemodal yang masuk. Perkara para pemodal itu kemudian masuk dan membangkrutkan potensi masyarakat kita sendiri, itu tidak jadi soal bagi mereka." (Hanum, hlm. 93).

"Jadi, dalam praktik, proses perampasan atas apa yang semula milik masyarakat menjadi milik negara yang disebut proses menuju pada 
kepentingan umum ini pada hakikatnya adalah proses penjajahan baru, penjajahan ekonomi, karena semuanya jelas berujung atas kekayaan masyarakat itu kekuatan ekonomi asing..." (Hanum, HIm. 139-140).

Kebijakan pemerintah yang dianggap tidak prorakyat pada akhirnya berdampak pada penghilangan sumber-sumber ekonomi atau penghasilan rakyat. Pedagang kecil, pemilik warung maupun pedagang kaki lima terpaksa harus menutup usahanya, sebab kalah bersaing dengan para pemodal dengan usaha yang sangat moderen. Penggunaan kata warung, kampung, dan desa bermakna konotasi, misalnya terisolasi, jauh keramaian, penduduk bekerja sebagai petani dan nelayan.

Teks [11] "Para pemilik warung di kampung dan desa yang selama ini berjualan di pasar tradisional banyak yang menutup usaha, karena kalah bersaing. Jumlah mereka yang kalah dan dikalahkan oleh persaingan bebas ini memang betul banyak, tetapi setiap hari terus bertambah." (Hanum, hlm. 74).

Pemerintah lebih mengutamakan kesenangan pihak atau golongan-golongan tertentu tanpa memikirkan nasib para rakyat. Mereka menjadi korban oleh pihak-pihak yang lain, pihak yang hanya mengutamakan kepentingan mereka sendiri.

Teks [12] "Dan oknum pemerintah itu akan dapat laba besar. Sementara para pedagang kecil dan masyarakat sekitar menjerit karena kehilangan tempat kerja dan kesempatan kerja, maka para oknum yang jahanam itu malah berpesta uang". "Inilah yang oleh seorang teman kuliahku disebut praktik kanibalisme ekonomi pasar bebas." (Hanum, hlm. 119).

Teks [12] terdapat dua kata ditulis miring secara semantik memiliki konotasi makna negatif, yaitu jahanam dan kanibalisme. Pemakai bahasa makian jahanam memiliki konotasi makna negatif, sedangkan kanibal merupakan metafora yang menunjukan sebuah ekspresi emosi yang kuat.

Secara harfiah "kanibalisme" mengacu pada jenis makhluk yang pemakan manusia. Secara konotasi tertuju pada kelompok orang yang berkuasa dan betindak semena-mena hingga merugikan pihak lain. Selain itu, frasa berpesta uang juga merupakan bentuk metafora yang digunakan pada teks.

Ini adalah bentuk penjajahan yang hingga saat ini belum merdeka, ketimpanganketimpangan ekonomi dan kesenjangan sosial terjadi di semua lapisan masyarakat. Dalil bahwa pembangunan adalah demi kesejahteraan rakyat hanyalah slogan, sebab kesejahteraan hanya dinikmati oleh kelompok tertentu saja.

Pengambilan paksa tanah rakyat untuk selanjutnya diserahkan kepada pihak-pihak perusahan atau swasta lainnya banyak berbuntut pada konflik fisik, ini dapat kita saksikan beberapa daerah di tanah air (kasus Mesuji dan Bima) yang akhirnya berbuntut pada konflik fisik yang menimbulkan korban jiwa.

\subsection{Praktik Kuasa pada Sektor Budaya}

Tyler (dalam Soekanto, 1990:188-189) mendefinisikan istilah kebudayaan sebagai berikut.

\begin{abstract}
"Kebudayaan adalah kompleks yang mencakup pengetahuan, kepercayaan, kesenian, moral, hukum, adat istiadat dan kemampuan-kemampuan lain serta kebiasaan-kebiasaan yang didapatkan oleh manusia sebagai anggota masyarakat."
\end{abstract}

Apabila dipemperhatikan definisi 'kebudayaan' yang disampaikan Tyler di atas dari aspek kesenian, moral, hukum, dan adat istiadat, maka sesungguhnya aspek-aspek kebudayaan sudah banyak yang terkikis oleh modernisasi yang saat ini berkembang.

Kondisi sosial kebudayaan dalam novel Hanum melalui pengarang menggambarkan bahwa perilaku, gaya (style) masyarakat mengalami perubahan. Masyarakat yang hidup di desa dengan cara-cara tradisional, terutama cara berpakaian telah mengikuti perkembangan di perkotaan yang serba modern. Mereka menganggap bahwa cara-cara berpakaian desa sudah ketinggalan zaman dan sudah kuno. Sebab itu, jika tidak mengikuti gaya hidup di perkotaan, maka dianggap tidak mengikuti zaman.

Perubahan perilaku hidup masyarakat akibat perkembangan dan kemajuan di perkotaan dengan system pembangunan yang tidak terkendali, serba modern ternyata 
menggeser budaya masyarakat berupa budaya berpakaian, budaya hidup, dan budaya membaca, terjadi karena hadirnya tempattempat perbelanjaan (mall, supermarket, hypermarket).

Tempat-tempat perbelanjaan ini semuanya milik pemodal dalam dan luar negeri yang memang memiliki daya tarik tersendiri bagi masyarakat mulai dari anak-anak, remaja, pemuda bahkan sampai pada orang tua. Namun daya tarik ini banyak mengarah keprilaku budaya-budaya asing yang memang jauh dari budaya bangsa.

Konflik akibat dominasi kuasa pada sektor budaya justru terjadi bukan karena masyarakat adalah kelompok awam. Namun kelompok berpendidikan, sehingga apa yang dilakukan sebagai bentuk sikap kritis terhadap praktik diskursif. Setiyanti (2017:116) mengatakan bahwa konflik budaya terjadi karena tingkat pendidikan rendah dengan perbedaan budaya mencolok. Hanya saja konflik pada Novel Hanum merupakan konflik yang terjadi akibat adanya faktor internal, yaitu praktik kuasa.

Dalam teks 13 dan 14 menampakkan bagaimana pengaruh modernisasi yang ditandai dengan pembangunan diberbagai sektor, terlebihnya pembangunan tempattempat perbelajaan modern dengan berbagai merek produk dagangan atau jualan, nyatanya dapat mengubah gaya hidup (life style) masyarakat, membuat mereka (masyarakat) cenderung berpikir materialistik, hedonis, dan pragmatis. Hal ini dapat dilihat dalam teks di bawah.

Teks [13] "Yang jelas pengaruh mall terhadap prilaku konsumsi sangat kuat. Bahkan boleh dikata, mall adalah lembaga pembentuk gaya hidup manusia kota. Juga menjadi lembaga pembentuk gaya hidup manusia desa. Saya temukan fakta kalau sebagian pengunjung mall adalah manusia desa yang bosan dengan gaya hidup pedesaan mereka selama ini" (Hanum, hlm. 73-74).

Teks [14] “...pengunjung tempat ini bukan para pembaca buku. Mereka datang ke tempat ini untuk mencari hiburan, bukan untuk berpikir. Mereka ingin mencari kesenangan, bukan mencari kegelisahan" (Hanum, hlm. 64).
Menyadari kondisi di atas, Linda pun tidak ingin terjebak dan terbawa dengan penetapan harga barang di tempat-tempat penjualan modern. Ia pun akhirnya memutuskan untuk berbelanja di tempat penjualan sederhana, sebab dapat menghemat pengeluaran jika dibandingkan dengang berbelanja di malll atau tempat perbelanjaan modern lainnya. Hal ini dapat dilihat pada teks 15 di bawah.

Teks [15] "Saya kan harus menabung untuk hari tua. Kalau dompet saya terkuras oleh mode terbaru dengan merk asli, maka tabungan kosong..." (Hanum, hlm. 68).

Pada teks 15 menggambarkan monopoli pasar dalam bentuk harga ternyata dapat mendobrak prilaku konsumen atau pembeli yang melampaui daya kebutuhan. Akhirnya, dapat menghilangkan budaya menabung di tengah-tengah masyarakat dan menciptakan cara-cara hidup boros. Prilaku kesadaran terhadap pengaruh modernisasi digambarkan dengan kalimat dompet saya terkuras.

\subsection{Konteks Konflik Politik}

Peristiwa-peristiwa yang terjadi dalam teks tentu ada konteks yang melatarinya. Menurut Darma (2014:65-67), konteks merupakan objek/benda atau hal yang mengikuti teks lalu menjadi situas atau lingkungan penggunaan bahasa. Dengan demikian, yang dimaksud konteks adalah segala hal yang bukan kategori unsur bahasa.

Konteks linguistik adalah konteks berupa unsur-unsur bahasa. Konteks ekstralinguistik mencakup praanggapan, partisipan, topik pembicaraan, dan latar, saluran bahasa. Weiss \& Wodak (2002:21) mengasumsikan wacana sebagai hubungan dialektika antara praktik diskursif tertentu dengan aksi secara khusus.

Konteks politik pada novel Hanum mencakup partisipan, topik pembicaraan, latar, dan saluran bahasa yang digunakan. Secara khusus konteks yang memunculkan adanya teks yang secara kait mengait terciptanya alur cerita.

Konteks konflik pada novel Hanum menempatkan partisipan sebagai kaum jelata yang melakukan perlawanan terhadap partisipan kelompok kuasa (penguasa). Hal ini 
kemudian munculnya kelompok sosial pada kelas sosial berbeda dalam memperjuangkan ideologinya.

Konteks ekstralinguistik muncul dan mengakibatkan teks wacana secara linguistik, baik kata, makna, tatakalimat sebagai fakta teks. Akan tetapi, aspek linguistik hadir dengan makna konotasi beragam, seperti penggunaan makian dan majas perumpamaan.

\section{Simpulan}

Berdasarkan analisis wacana kritis, diketahui bahwa konflik pada novel Hanum muncul akibat adanya praktik kuasa pada sektor kehidupan, seperti hukum, ekonomi, dan budaya. Konflik terjadi ketika dua kepentingan kelompok atau pihak yang berbeda, yaitu masyarakat dan pemerintah.

Konflik muncul pada tataran linguistik, baik kosakata, makna (semantik), dan tatakalimat. Unsur linguistik ini digunakan sebagai modus kuasa sebagai bentuk intervensi hukum, ekonomi, dan kebudayaan. Secara kaidah partisipan saling menggunakan bahasa dengan intonasi tinggi. Hal ini menunjukkan bahwa kekuasan di balik kaidah justru menjadi alat kekuatan bagi partisipan yang melakukan perlawanan. Sementara pihak berkuasa dengan gaya bahasa terkesan tidak memaksa, jika dikaji secara harfiah. Hal ini mengindikasikan adanya pengaturan wacana yang berlaku secara negatif, seperti sanksi-sanksi yang akan dirasakan pihak-pihak tertentu.

Penggunaan bahasa makian dan metafora menunjukan sebuah ekspresi emosional yang sangat kuat. Kosa kata menjadi sarana kekuatan, baik partisipan kuasa dan partisipan tidak kuasa. Hal ini dapat dilihat pada penggunaan kata jahanam dan kanibalisme yang mengacu pada jenis makhluk yang pemakan manusia. Secara konotasi, tertuju pada kelompok orang yang berkuasa dan betindak semena-mena hingga merugikan pihak lain.

Dimensi teks (discourse), praktik wacana (discourse practice), dan praktik sosial dan budaya (social-culture practice) menjadi hubungan yang sangat paradoksal serta ideologis. Tiga pembatasan berkaitan dengan isi, relasi, dan partisipan muncul sebagai konflik yang negatif. Secara tegas konflik ini terjadi antar partisipan untuk saling mendominasi identitas sosialnya.

Temuan pada penelitian ini dapat dijadikan informasi tentang bagaimana kehidupan sosial, politik, hukum, dan budaya di tengah-tengah masyarakat. Apakah bersifat fakta atau fiktif tentu bukan itu yang diinginkan, melainkan pesan-pesan pendidikan, sosial, dan budaya itu yang patut direnungi.

\section{Daftar Pustaka}

Abadi, H. S. 2017. Kekuasaan Seksualitas dalam Novel: Perspektif Analisis Wacana Kritis Michel Foucault. Belajar Bahasa, 2(2).

Bahasa, P. 2010. Kendali Interaksional Sebagai Cerminan Ideologi: Analisis Wacana Kritis Trilogi Drama Opera Kecoa. Masyarakat Linguistik Indonesia, 11.

Budiwati, T. R. 2011. Representasi Wacana Gender dalam Ungkapan Berbahasa Indonesia dan Bahasa Inggris: Analisis Wacana Kritis. Jurnal Kawistara, 1(3).

Creswll. J. W. 2014. Research Design: Pendekatan Kualitatif, Kuantitatif, dan Mixed. Jakarta: Pustaka Pelajar.

Creswll. J. W., Miller, D.L. 2000. Determining Validity in Qualitative Inquiry. Theory Pract. 39, 124-130. Canada: Canadian Publication.

Darma A. Yoce. Analisis Wacana Kritis dalam Multiperspektif. Bandung: PT Rfaika Aditama.

Djatmiko, Yayat Hayati. 2008. Perilaku Organisasi. Bandung: Alfabeta.

Fairclough, N. 1989. Language and Power: Relasi Bahasa, Kekuasaan dan Ideologi. Terjemahan oleh Indah Rohmani. 2003. Malang: Boyan Publishing.

-------.-1995. Critical Discource Analysis: Critical Study of Language. New York: Longman Group UK Ltd.

Kritis. IKIP Semarang Press.

Februana, Ngalim. 1994. "Konflik Sosial dan Politik dalam Novel Nyali Karya Putu Wijaya: Sebuah Tinjauan Sosiologi 
Sastra”.(Skripsi). Fakultas Sastra, Universitas Gadjah Mada.

Hasyim M.W. 2009. Hanum. Jakarta: Republika.

Jorgensen, M. \& Phillips, L. 2002. Discourse Analysis as Theory and Method. London: SAGE Publications Ltd.

MM, J. 2009. Sejarah Sastra adalah Sejarah Sebuah Bangsa: Ketika Yogyakarta Menjadi Indonesia.

Noor, M, Rohinah. 2011. Pendidikan Karakter Berbasis Sastra: Solusi Pendidikan Moral Yang Efektif. Jogjakarta: Ar- Ruzz Media.

Nurgiyantoro, Burhan. 2017. Stilistika. Yogyakarta: Gadjah Mada University Press.

Putri, M. E., dkk., 2013. Ideologi Tokoh Utama (Wanita) dan Tokoh Tambahan dalam Novel Hanum Karya Mustofa WH. Pendidikan Bahasa dan Sastra Indonesia, 1(2), 506-512.

Rahardjo S. 2008. Biarkan Hukum Mengalir. Jakarta: Buku Kompas.

Rohman A. 2009. Politik Pendidikan. Yogyakarta: Laks Bang Media Utama.

Santoso, A. 2012. Studi Bahasa Kritis: Menguak Bahasa Membongkar Kuasa. Bandung: Mandar Maju.

Setiyanti, A. 2017. Konflik Sosial pada Tokoh Utama dalam novel I Am Malala Karya Christina Lamb. Bahtera: Jurnal Pendidikan Bahasa dan Sastra, 14(2), 103.

https://doi.org/10.21009/BAHTERA.142. 01

Sipayung, M. E. 2016. Konflik Sosial dalam Novel Maryam karya Okky Madasari: Kajian Sosiologi Sastra. Sintesis, 10(1), 22-34.

Soekanto, Soejono. 2007. Sosiologi Suatu Pengantar. Jakarta: Rajawali Press.

Soekanto, Soerjono. 1990. Sosiologi Suatu Pengantar. Jakarta: Rajawali Press.

Tololi, Nani. 2000. Kajian Sastra. Gorontalo: Nurul Jannah.

Wardani, IG. A. K. 1981. Pengajaran Apresiasi Prosa. Jakarta: Depdiknas.

Weiss G. dan Wodak, R. (ed). 2003. Critical Discourse Analysis. London: University Press. 